\begin{tabular}{c} 
JNE 5(1) (2019) \\
UNNES \\
Jttp://journal.unnes.ac.id/nju/index.php/jne \\
\hline
\end{tabular}

\title{
Business and Industry World Contributions to Community Empowerment
}

\author{
Wiwin Herwina ${ }^{凶}$, Mustakim
}

Community Education Departement, Faculity of Teacher Training and Education, Siliwangi University, Indonesia

DOI: http://dx.doi.org/10.17751/jne.v5i1

\begin{abstract}
Articles Info
History Articles:

Received 14 January 2019

Approved 26 January 2019

Published February 2019

\section{Keywords:}

Business word,

Industry word, community

empowerment

Abstract

The development of the business and the industry world goes hand in hand with the development of education in society. Education plays an important role in improving people's life skills. The purpose of this study is to describe the contribution of the business world and the world of industry in community empowerment, and to describe the concept of community empowerment for alumni of the Yuwita training and course institution, Tasikmalaya City, West Java. This study uses a qualitative method with a descriptive approach. The techniques used in collecting research data are observation techniques, indepth interviews, and documentation. Whereas for checking the validity of the data the researcher uses data validity criteria to support that this research has credibility, transferability, dependability, and confirmation. The results of the study illustrate that the business and the industry world (DUDI) contribute to the empowerment of alumni communities in courses and training in skin beauty. DUDI's contribution to community empowerment manifests itself in increasing independence, the formation of study groups, competencies that are in accordance with the Indonesian National Qualification Framework Standard (SKKNI). Increasing entrepreneurship based on regional potential, increasing skills, knowledge and attitudes. And increasing economic capacity, ability to access welfare benefits, and cultural and political abilities. A partnership between courses and training institutions with DUDI was realized. Collaboration in technology transfer, knowledge/skills transfer, human resource transfer, transfer of learning methods, and capital transfers, as well as business opportunities.
\end{abstract}

(C) 2019 PLS PPs UNNES

\footnotetext{
Address correspondence:

Community Education Departement, Faculity of Teacher Training and Education,

Siliwangi University

Street Siliwangi No. 24 Kahuripan Tawang Kota Tasikmalaya Provinsi Jawa Barat p-ISSN 2442-532X

e-ISSN 2528-4541

46115, Indonesia

E-mail: wiwinherwina@unsil.ac.id
} 


\section{INTRODUCTION}

Educated unemployment is a
fundamental problem in the current technological era. Incessant modern technology that replaces the participation of humans with machines in various sectors. The development of human resources is the responsibility of the government and society. Indonesia's Human Development Index (HDI) data about "women's empowerment" menggambarkan bahwa "...13 woman-specific empowerment indicators that allows empowerment to be compared across three dimensions reproductive health and family planning, violence against girls and women and socioeconomic empowerment. Three color coding visualizes a partial grouping of countries by indicator. Most countries have at least one indicator in each tercile, which implies that women's empowerment is unequal across indicators and countries (Human Development Indices, 2018).

The HDI data illustrates that three important dimensions of women's empowerment are (1) reproductive health and family planning, (2) violence against children and women, and (3) socio-economic empowerment. The three dimensions of empowerment are the top priority scale. Related to the business world and the industrial world, the dimensions of women's empowerment are more inclined to the dimensions of economic social empowerment.

Community empowerment is "providing people with the resources, opportunities, knowledge, and skills to increase their capacity to determine their own future, and to participate in and affect the life of their community" (Ife, 1995). So that empowered people can improve their economy. "The ability to empower their economy is also due to the freedom in making decisions; they have the power to decide on what to do with their income" (Zal, Redzuan and Samah, 2013).

The freedom of the community in making decisions is an indicator of the economic empowerment of the community. Community empowerment must be done in at least three ways (1) creating an atmosphere or climate that allows the potential of the community to develop, (2) strengthening the potential or power possessed by the people by implementing concrete steps, accommodating various inputs, providing infrastructure and facilities both physically and socially that can be accessed by the community at the most bottom, (3) empowering the people in the sense of protecting and defending the interests of the weak community (Hadi, 2014).

With the development of potential in the community, the economy will develop in the community. As well as cross-sectoral cooperation between the business world and the industrial world. While "...businesses should include the cooperation of academics who conduct research on the management of small industry enterprises, the local government which makes policies to support the development of SMEs and commerce businesses, and craftsmanship organizations to facilitate human capital reinvigoration" (Saraswati, 2018).

The development of the business world and the industrial world goes hand in hand with the development of education in society. Education plays an important role in improving people's life skills. Especially alumni are governance courses and training institutions. Alumni's personal development can be in the form of soft skills and hard skills. Education and community empowerment can be realized if there is "...Self Help Groups (SHG) plays a significant role in the empowerment of women (Dhani, 2017).

The business group as a place to learn and exchange experiences between alumni in the skin beauty course in the City of Tasikmalaya. Members of the average group of alumni are between the ages of $18-45$ years. In the age range, it is a productive period in developing skills and life skills. Age in particular is of increasing importance, as previous research has highlighted the importance of the socialization of an age cohort (generation) for the manifestation of own values, attitudes, expectations and the ideology affecting a worker's behaviour and, consequently, his or her 
attitude towards empowerment (Singh and Weimar, 2017).

Community empowerment in courses and training is more emphasized on hard skills. Whereas the business world and the industrial world put forward soft skills. Soft skills such as the formation of values, attitudes, work behavior, ethics and good communication skills. Community empowerment is part of non-formal education.

Nonformal education according to the national education system article 26 includes: (1) Non-formal education is held for citizens who need educational services that function as substitutes, enhancers, and/ or complementary formal education in order to support lifelong education. (2) Non-formal education functions to develop the potential of students with an emphasis on mastering knowledge, functional skills and the development of professional attitudes and personalities. (3) Non-formal education includes life skills education, early childhood education, youth education, women's empowerment education, literacy education, skills education and job training, equality education, and other education aimed at developing students' abilities. (4) Courses and training are held for people who need knowledge, skills, life skills, and attitudes to develop themselves, develop their profession, work, independent business, and / or continue their education to a higher level (Sisdiknas, 2003).

Through non-formal education, community empowerment can be easily accepted by adults. With the hope that adults can be empowered quickly and have the skills, professional development that is in accordance with the world of work alumni beauty courses. Therefore, in achieving adult empowerment, it is determined by directed goals and in accordance with the target.

Community empowerment is often not in accordance with the demands of the business and industry world. This condition occurs in adults, therefore "...continued efforts are needed to clearly specify the factors that put older adults at risk for low levels of perceived empowerment, thus more clearly targeting the causes for lack of empowerment and the design and evaluation of relevant and effective interventions (Shearer $e t$ al., 2012).

This research was conducted at the Yuwita courses and training institute in the City of Tasikmalaya, West Java Province, Indonesia. The study aims to describe the contribution of the business and industry world in community empowerment, and the concept of community empowerment for alumni, courses and training institutions. To get the latest insights into the contribution of the business and industry world. This research uses a bottom-up approach. Related to the proposal in this study, then researchers want to explore further the title of the research about "The Contribution of the Business and Industry World in Community Empowerment to Alumni of Courses and Training Institutions".

\section{METHODS}

The title of this study is the contribution of business and industry world in community empowerment to alumni of courses and training institutions. This study uses a qualitative method with a descriptive approach. Qualitative methods is "research methods based on postpositivism philosophy, used to examine natural object conditions, (as opposed to experiments) where researchers are key instruments, data collection techniques are triangulated (combined), data analysis is inductive/ qualitative, and the results of qualitative research emphasize the meaning rather than generalization"(Sugiyono, 2012).

The techniques used in collecting research data are observation techniques, indepth interviews, and documentation. While for checking the validity of the data the researcher uses data validity criteria to support that this research has credibility, transferability, dependability, and confirmation (Moleong, 2011). 


\section{RESULTS AND DISCUSSION}

\section{The Contribution of the Business World and the Industry World in Community Empowerment}

The business and industry world are the spearhead in the country's economic system. A country that has a good economic system if the community is empowered and contributes actively in business and industry. In principle, the business world and the industrial world are related to community empowerment. The principle of empowering micro, small and medium enterprises (MSMEs) according to Law No. 20 of 2008 including: (1) Growth in the independence, togetherness and entrepreneurship of MSMEs. (2) The realization of public policies that are transparent, accountable and fair. (3) Regional potential and market-oriented business development in accordance with MSMEs competencies, (4) Increasing competitiveness of MSMEs, (5) Implementing planning, implementation, and integrated control (UMKM, 2008).

Industrial empowerment in this case relates to the empowerment of industrial communities. On industrial empowerment as contained in article 72 of Law No. 3 of 2014 concerning Industry including: (1) The Government and/ or Regional Government undertakes the development and empowerment of small and medium industries to realize small and medium industries which: (a) are competitive, (b) play a significant role in strengthening the structure of the national industry, (c) play a role in poverty alleviation through expansion employment opportunity; and (d) produce industrial goods and / or services for export (Perindustrian, 2014).

DUDI's (business and industry world) contribution in community empowerment in this study relates to alumni of courses on courses and training in skin beauty planning in the City of Tasikmalaya. The contribution of the business community in the empowerment of the skin beauty system from independence can be seen that graduates of courses and training in skin beauty can create their own business opportunities. For example, establishing a beauty salon business, working in a skin and hair beauty clinic, and working with a wedding organizer. As for the togetherness that alumni graduated from skin beauty form small groups both formally and formally. Like the learning community that is hosted by the Yuwita Skin Beauty Course and Training Institute and the Tiara Kusuma Branch Board. Entrepreneurship alumni from the skin beauty course are alumni who pursue a small-scale home salon business.

The realization of public policies that are transparent, accountable, and equitable in the empowerment of graduates of skin beauty courses and training courses are: (1) alumni from skin beauty courses and training have the legality of certificate of expertise from the Competency Certification Institute (LSK) for skin beauty. Therefore the certificate of competence in skin beauty has legal strength. (2) Government policies that provide specifications for skin beauty graduates to have special competencies through Professional Certification Institutions (LSP) in accordance with the Indonesian National Qualification Framework Standards (SKKNI).

The contribution of the MSMEs in Tasikmalaya City in the improvement of new alumni entrepreneurship in the area-based and job-market-based skin beauty courses. DUDI's contribution to community empowerment includes activities such as: (1) graduates' creativity in skin care in MSMEs buildings, (2) appreciation of City and Provincial skin beauty systems, (3) New Business Entrepreneurship program (WUB) for beauty alumni kulit which collaborates with the City Education Office and the Industry Service, Tasikmalaya city.

Increasing competitiveness is DUDI's contribution in community empowerment. Increased competitiveness is reflected in the alumni of the skin beauty program, getting increased skills, knowledge and attitudes. Improved soft skills such as communication skills, skills in work preparation that are in accordance with health principles and work 
safety in the skin care, communication skills both orally and in writing, and leadership.

Increased knowledge is reflected in the daily activities of alumni in skin care. Knowledge gained by alumni on skin beauty is the knowledge of using new technology, the introduction of new beauty products, and getting information on the latest techniques in skin beauty.

Increased attitudes are reflected in teamwork, ability to argue, socialize, ability to solve problems, ethics, courtesy, good speech, time discipline, and moral values.

\section{The Concept of Community Empowerment for} Alumni of Courses and Training Institutions

Empowerment is a process and purpose (Suharto, 2010). As a process that empowerment is a series of activities to strengthen power or empowerment of weak groups in society. Whereas as a goal that empowerment refers to the condition to be achieved by a social change. Social change means that the community is empowered, has the knowledge and ability to fulfill their needs both physically, economically, self-confidence, is able to express aspirations, have a livelihood, can participate in social activities, and be independent.

Community empowerment basically aims to increase the potential of the community. So that it can improve the quality of life better. Empowering people aims, "educating people to be able to educate themselves" or "helping people to be able to help themselves". In the sense that in the process of empowerment that occurs, the community plays an active role in designing empowerment itself.

The purpose of community empowerment is to improve the quality of human resources. Through non-formal education which is a priority in the community. Thus, a result of community empowerment will be achieved in the form of an independent, self-reliant society, capable of adopting innovation, and having a cosmopolitan mindset.
The empowerment of the community for alumni in the course and training in skin beauty planning in the implementation is reviewed from the indicators of empowerment. Indicators of empowerment are three aspects, including: (1) economic capacity, (2) ability to access welfare benefits, and (3) cultural and political abilities (Suharto, 2010).

In alumni courses and skin beauty training, the concept of empowerment refers to indicators of empowerment. Graduates of courses and training are given empowerment to have economic abilities. Economic ability in this case is the ability to meet his needs as well as his family. Have the same economic opportunities as other communities and have equal rights to existing resources in family and society.

The ability to access welfare benefits in this case is alumni courses and training have confidence and happiness, have the same welfare among members of the community, can make decisions for themselves and others, can control the number of children in the family.

Cultural and political abilities, namely that alumni courses and training in skin beauty can be directly involved in cultural, legal and political processes in everyday life. Able to adapt to cultural traditions, legal discrimination, and political exclusion.

Community empowerment is human activity that has structural and organizational aspects, which are aimed at changing social systems and creating structural alternatives. Community empowerment is seen as the right strategy to empower and improve the living standards of the wider community. And "...empowering that individual to be in greater command of his or her destiny (Wilson, 2013).

Community empowerment is an effort to enable and empower the community (Fahrudin, 2012), with the following efforts: Enabling is creating an atmosphere or climate that allows the potential of the community to develop. The starting point is the introduction that every human being, every society has 
potential that can be developed. Empowerment is an effort to build that power by encouraging, motivating and raising awareness of its potential and trying to develop it.

Empowering is increasing capacity by strengthening the potential or power possessed by the community. This strengthening includes concrete steps such as the provision of various inputs (inputs) and opening up access to various opportunities that can make the community more empowered.

Protecting is protecting interests by developing a protection system for people who are the subject of development. In the empowerment process the weak must be prevented from becoming weaker, because of lack of power in the face of the strong. Protecting in this case is seen as an effort to prevent unbalanced competition and strong exploitation of the weak.

According to Petter et al (Pitts, 2005) formulate a comprehensive definition of empowerment that includes seven dimensions: power, decision making, informa- tion, autonomy, initiative and creativity, knowledge and skills, and respon- sibility. Community empowerment is seen as the right strategy to empower and improve people's lives. Every society has different traditions and customs. These customs can be potential developed as social capital. For this reason, the right strategy and approach is needed in community empowerment.

Strategies in community empowerment, especially alumni courses and training depend on the potential to be developed, the capacity of empowered communities and protect the people who will be empowered so that they do not return to their previous conditions. "...the success of any strategy relating to women empowerment depends on the level of education, social participation, hard work of women (Dhani, 2017).

Community empowerment considers the right strategies to empower and improve people's lives. But keep in mind that every society has different traditions and customs.
For this reason, in an effort to empower the community, the right strategy and approach is needed. In addition, it is also necessary to discuss community empowerment in the context of various approaches that can be seen as alternative ways of implementing community empowerment.

There are four principles that are often used for the success of empowerment programs. They are the principle of equality, participation, self-reliance or independence, and sustainable (Najiati, Sri, 2005). The explanation of the principles of community empowerment are as follows:

The main principle that must be held in the process of community empowerment is the equality of position between the community and the institutions that carry out community empowerment programs, both men and women. The dynamics that are built are the relationship of equality by developing a mechanism for various knowledge, experience, and expertise with each other. Each acknowledges each other's strengths and weaknesses, so that there is a mutual learning process.

Empowerment program that can stimulate community independence. It is a program that is participatory in nature, planned, implemented, monitored, and evaluated by the community. However, to get to that level it takes time and a mentoring process that involves assistants who are highly committed to community empowerment

The principle of self-reliance is to respect and prioritize people's abilities rather than the assistance of others. This concept does not view the poor as an incapable object, but as a subject with little ability. They have the ability to save, deep knowledge of the constraints of their business, know their environmental conditions, have labor and willingness, and have community norms that have long been obeyed. All of that must be explored and used as the basic capital for the empowerment process. Assistance from other people who are material must be seen as supporting, so that the 
provision of assistance does not weaken their self-sufficiency.

Empowerment programs need to be designed to be sustainable, even though at first the role of facilitator was more dominant than the community itself. But slowly and surely, the role of companion will diminish. In fact, it was finally deleted, because the community was able to manage its own activities.

Basically, the success of the principles of community empowerment is very dependent on the conditions of the people who are targeted by the program. With the empowerment strategy and the principles of empowerment, the community can have knowledge, skills, experience, and independence. If empowerment strategies seek to have an emancipatory effect on people who are marginalized and discriminated against, they must go beyond developmental goals, such as higher productivity, higher consumption and higher formal education (Jönsson, 2010).

Community empowerment strategies that can be implemented on alumni courses and training are delivered through partnerships. Partnership is not merely translated as a collaboration, but partnerships have a pattern, a strategic value in realizing the success of an institution in implementing modern management. Partnership in the implementation of modern management is an understanding of program management, understanding of program empowerment strategies among partner institutions.

Partnerships can be carried out in technology transfer, knowledge transfer, transfer of human resources, transfer of learning methods, capital transfers, or various things that can be seconded so that they are integrated in a complete form. The concept of partnership has a principle that must be an understanding among partners and must be enforced in its implementation including: the principle of participation, the principle of mutual cooperation, the principle of openness, principles of law enforcement (rights and obligations, leading to right-obligation, reward and punishment) and the principle of sustainability.

In the process of empowering human resources, a partnership is needed between communities with the business world and the industrial world. Partnership in the Indonesian society is something that is not foreign to apply. Because this nation has known partnerships for centuries even though on a simple scale, such as mutual cooperation, participation, cai partners, forest village community partners, environmental partners and others.

Business and industry are economic institutions that can be used as partners. In empowering the community, especially in fostering (controlling), managing, and marketing the product. This is done so that the production produced by the community is truly high quality. For this purpose, the partnership in empowering community businesses with DUDI is very necessary for small and medium entrepreneurs.

The aim of the partnership network is to facilitate and optimize all existing potential in the context of conducting business programs. So that the program objectives are achieved in accordance with the plan to empower training alumni. In addition, the purpose of empowering the partnership model is to formulate an effective model of partnership in organizing community business programs with the business world and the industrial world.

Benefits of partnership between alumni training in skin beauty planning with the business world and the industrial world. They are: (1) Efficiency and effectiveness that is able to provide beauty services to customers quickly and precisely by using resources in large quantities and quality; (2) Guaranteed quality, quantity and sustainability starting from the input provider, process to the output produced; (3) Reducing risk and increasing profits; (4) Giving social benefits; (5) Increasing income and welfare; (6) Support the sustainability of the program. 
Partner institutions in this case "TIARA KUSUMA", They are Beauty Experts Association and Indonesian Salon Entrepreneurs partnering with DUDI. The role of organizational institutions in this regard is: (a) Business institutions/ entrepreneurs, as: organizers, facilities providers, tutors, fund providers and markets, business partners. (b) The institution is able to analyze the possibilities of empowering the partnership network in the framework of the activity program.

The business world and the industrial world have characteristics as institutions that are very oriented to aspects of quality and aspects of profit. Modern DUDI facilities can generate multiple profits. So, to improve human resources all elements related to DUDI must work together. The three elements of the tricenter of education (the paradigm of the family, school and community relations paradigm) must be in synergy to improve the quality of education services. With quality education services, it will produce graduates of quality skin beauty. The quality of graduates will be recruited by the business world and industry.

The steps for implementing a partnership between Alumi's skin beauty course with the business world and industry are as follows: Internal Identification of Institutions, at this stage the institution identifies components that have not been owned for the implementation of the program. The first step that must be done is that the institution assesses what components must exist in the implementation of the program. For example, in the implementation of training programs to improve the quality of human resources, which must be prepared including; buildings, equipment, teaching materials, equipment, trainers, participants and funds. Of the needs needed by all institutions, if there are those that have not been fulfilled, then the needs that must be met for the implementation of the program.

Formulate aspects that need to be partners, From the results of identification activities, the next step is to prioritize needs. Based on the identification data from this activity, it will be known which components will be partnered first. Based on the stages of program implementation activities and also formulating the criteria identified by the institution. Aspects that will be needed for the implementation of the program. And these needs will be aspects that will be partnered with other institutions and also determine the criteria for prospective partners.

After knowing the components that will be partnered. The next step is to look for prospective partner institutions that meet the specified needs and criteria. Make an agreement with a prospective partner institution. After a candidate has been determined based on the required criteria. The next step is making agreements regarding the rights and obligations of the work partners, the decision is based on the agreement of both parties. Then make the rules agreed upon together, which will guide the two parties in the framework of implementing the partnership network.

Having established a partnership between alumni courses and skin beauty training with the business world and the industrial world. Then the next activity is mentoring. Mentoring is an activity carried out by someone who is consultative, that is creating a condition. So that the companion and those who are accompanied can consult solving problems together. Interactive between the companion and those who are accompanied must be equally active. Communicative is what is conveyed by the companion or which is accompanied can be understood together (equality of understanding). Motivative is a companion must be able to foster self-confidence and can provide encouragement/ motivation. And negotiations are companions and those who are accompanied are easy to make adjustments. Mentoring emphasizes the full facilitation of alumni in applying the abilities their mastered in the context of the business field.

Mentoring aims to help alumni or groups in empowering their businesses (optimizing their potential) to be able to be independent. Through this assistance, it is hoped that the community 
will get various efforts to learn and realize a lifelong learning process in accordance with the conditions and potential available in their environment. Assistance to alumni courses and training is conducted in each group. Each group is facilitated by a companion.

The role must be performed by a companion according to the scope of the companion. The roles that must be played by the companion are "as a facilitator, motivator, and catalyst". If adapted in community empowerment activities in order to strengthen entrepreneurship as follows.

Facilitator, a companion is expected to be able to coordinate the resources around the community. These resources are divided into human and non-human resources that enable entrepreneurial activities and empowerment to develop optimally.

Motivator, the success of a companion is determined by the ability to motivate the community, the ability to mobilize the community for themselves for the common good.

Catalyst, to bridge alumni with other communities and big businessman of DUDI. A companion is required to play an active role as a liaison. In order to be able to carry out their role well, the companion must be present in the midst of the community, live with the community and explore the lives of the community. Regular attendance can help solve problems that occur in the group for the empowerment of groups that are increasingly steady towards self-discovery and self-confidence.

Companion tasks in detail include: (a) Identifying needs, analyzing and verifying data; (b) Conducting surveys to obtain data and facts (empirical) on the target alumni of empowerment; (c) Facilitating skills training; (d) Facilitating the empowerment of self-reliance (entrepreneurship); (e) Facilitating the planning, implementation, evaluation and monitoring of empowerment activities programs.

\section{CONCLUSION}

The contribution of the business world and industry in community empowerment is manifested in the independence of alumni in creating business opportunities, the formation of learning communities, having competencies that are in accordance with the Indonesian National Qualification Framework Standards (SKKNI). As well as enhancing entrepreneurship based on regional potential, namely by (1) the creative vision of graduates of skin beauty in the UMKM (MSMEs) building, (2) appreciation of the city and provincial skin beauty arts, (3) the New Business Entrepreneurship program (WUB) for skin beauty in collaboration with the City Education Office and the Industry Service, Tasikmalaya city.

On competitiveness, alumni get an increase in skills, knowledge, and attitude. Enhancing soft skills such as communication skills, skills in work preparation that are in accordance with the principles of occupational health principles and work safety in the skin care, communication skills both orally and in writing, and leadership. Increased knowledge of knowledge using new technology, the introduction of new beauty products, and getting information on the latest techniques in skin care. As well as improving attitudes which are reflected in teamwork, ability to argue, socialize, ability to solve problems, ethics, courtesy, good speech, time discipline, and moral values.

The concept of community empowerment for alumni of course institutions and training materialized in improving economic capacity, ability to access welfare benefits, and cultural and political abilities. that there will be a partnership between course institutions and training with the business world and the industrial world. Collaboration can be realized in technology transfer, knowledge / skills transfer, human resource transfer, transfer of learning methods, and capital transfers, as well as business opportunities. 


\section{REFERENCES}

Fahrudin, A. (2011). Pemberdayaan, Partisipasi dan Penguatan Kapasitas Masyarakat. Bandung: Humaniora.

Hadi, S. (2014). Pemberdayaan Ekonomi Rakyat Melalui Penguatan Manajemen Organisasi Di Indonesia. Jurnal Fakultas Hukum UII, 14(1), 39-66.

Human Development Indices. (2018). Human Development Indices and Indicators: 2018 Statistical Update.

Ife, J. (1995). Community Development: Creating Community Alternatives, Vision. Analysis and Practice. Australia: Longman.

Jönsson, J. H. (2010). Beyond empowerment: Changing local communities. International Social Work, 53(3), 393-406.

Mathur, P., \& Agarwal, P. (2017). Self Help Group: A Strategic Tool for Women Empowerment. Pertanika Journal of Social Sciences \& Humanities, 25(2).

Moleong, L. J. (2011). Metodologi Penelitian Kualitatif, cetakan XXIX. Bandung: PT. Remaja, Rosdakarya.

Najiati, S., Asmana, A., \& Suryadiputra, I. N. N. (2005). Pemberdayaan masyarakat di lahan gambut. Wetlands International Indonesia Programme.

Pitts, D. W. (2005). Leadership, empowerment, and public organizations. Review of Public Personnel Administration, 25(1), 5-28.

Saraswati, L. A. (2018). Social Sciences \& Humanities Production Efficiency Analysis for Empowerment Strategy of Troso Weaving Craft Micro, Small, and Medium Enterprises ( SMES ) in Jepara Central Java. 26, 193-198.
Shearer, N. B., Fleury, J., Ward, K. A., \& O'Brien, A. M. (2012). Empowerment interventions for older adults. Western journal of nursing research, 34(1), 24-51.

Singh, U., \& Weimar, D. (2017). Empowerment among generations. German Journal of Human Resource Management, 31(4), 307-328.

Sisdiknas (2003) Sistem Pendidikan Nasional. Jakarta.

Sugiyono. (2012). Metode Penelitian Kuantitatif Kualitatif dan R\&D. Bandung: Alfabeta.

Suharto, E. (2010). Membangun masyarakat, memberdayakan rakyat: Kajian strategis pembangunan kesejahteraan sosial dan pekerjaan sosial. Refika Aditama.

UMKM, U. R. I. T. (2008) UU RI No. 20 Tahun 2008 Tentang Usaha Mikro, Kecil dan Menengah.

Wilson, C. B. J. P. (2013) Experiential learning. London and Philadelphia: Digital Publishing Solutions, Printed and bound in the United States by Thomson-Shore, Inc.

Zal, W. A. A., Redzuan, M. R. and Samah, A. A. (2013). Social Sciences \& Humanities The Exploration of Social Capital and Its Relation with Economic Empowerment of Orang Kuala in Johor, Malaysia. 21(4), 1275-1295. 